\title{
When Multicultural Education Crashes upon Icebergs-The Cultural Gap
}

\author{
Apostolia Matziouri ${ }^{1, *}$ \\ ${ }^{1}$ Omonoias 6, Nea Herakleitsa, Kavala, Postal Code 64007, Greece \\ *Corresponding author: Omonoias 6, Nea Herakleitsa, Kavala, Postal Code 64007, Greece. \\ Tel: 30-259-402-3702. E-mail: polinapegasou@gmail.com
}

Received: April 15, $2020 \quad$ Accepted: April 26, 2020 Published: May 6, 2020

doi:10.5296/ije.v12i2.16854 URL: https://doi.org/10.5296/ije.v12i2.16854

\begin{abstract}
This article is our third attempt to give out evidence resulting from a large-scale and revealing research that took place in a regional unity of Northern Greece. Our goal is to trigger speculation and dialogue inside the scientific community regarding aspects of foreign students' cultural backgrounds and their attitude inside school. The article begins with a short theoretical frame, continues with the methodology and the findings, providing quotes that reveal a lot, especially after the recent alarming political upheavals in Eastern Mediterranean and ends with some excruciating questions intended to awaken native people's conscience.
\end{abstract}

Keywords: multicultural education, qualitative research, semi-structured interviews, cultural gap 


\section{Introduction}

So far, the literature has been spent on references to school curricula content, school timetable, material and textbooks, initiatives and projects, teaching methods, styles of school management, classroom structures, proposed or developed in each national context (Luciak, 2006). Moreover, research has focused on such issues as the national legislation concerning foreign pupils, measures adopted by the State (Skrefsrud, 2018; Hearnden \& Sundaram, 2011; Gropas \& Triandafyllidou, 2011) and the priority given by the state to multicultural education (Darling-Hammond \& Lieberman, 2012; OECD, 2014; Ogrodzka- Mazur, 2018; Taguma, Shewbridge, Huttowa, \& Hoffman, 2009). Additionally, throughout the decades, all those researchers who suggested ways of strengthening multicultural education, placed huge part of the responsibility on the school head and the teacher to take up measures against racism (Gillborn, 1995; Ryan, 2003; Grogan \& Andrews, 2002, p. 250; McCabe \& McCarthy, 2005, p. 204; March, \& Simon, 1958 \&1993; English, 2006, p. 2). Furthermore, school heads and teachers were accused of lacking qualifications, skills and knowledge to handle difficulties in the new multicultural school (Taguma et al., 2009: 8; Darling- Hammond \& Lieberman 2012: 159; Grant, 1990; Yeo, 1997; Spinthourakis, 2006; Parthenis, 2014) or being prejudiced against foreign pupils (Parthenis \& Fragoulis, 2016; Kontogiannopoulou-Polydorides \& Fragoulis, 2009). Rarely did those academics focus on the objective obstacles faced by teachers and heads, when, for example, foreign students show stubbornness and refuse to incorporate. That becomes clear in school units where the school population consists exclusively of "different" students and, therefore, no one can claim that they are rejected by "mainstream" students, that their cultural background is not appreciated by school community, or that they are deprived of equal opportunities (Furman \& Starratt's, 2002; Furman \& Shields, 2004; Dantley \& Tillman, 2006; Blount, 2006; Sleeter, 2013) etc. In sum, teacher has always been the scapegoat for every failure recorded in school.

Moreover, so far, only one viewpoint of the issue has been advanced: the one in favor of multicultural education and globalization. So, all those advocates of pluralism never hear or allow the view of those who, express skepticism, be heard.

Starting from this article, we will discuss various aspects of intercultural education thematically, giving a multitude of responses from many different subjects aiming at helping reader understand separate dimensions of the phenomenon and not be confused.

\section{Methodology}

The main purpose of a sociological research is to trace the latest sociological data and inform both the scientific community and the public about the prevailing views and attitudes, the composition and characteristics of the population, social conflicts etc. In parallel, science must serve the prosperity of societies through rational thinking and logic.

Thus, during our master studies in 2013, we carried out a research in a regional unity of Northern Greece, which consisted of 51 semi-structured interviews, (with a duration of 30 mins. - 1:45 hrs.), taken from school directors/sses serving in both rural and urban regions, 
School Coordinators, the Regional Director of Education and the Projects' Officer. The aim of the study was to explore the views of the aforementioned on various components of the intercultural approach. One of our ultimate goals was to investigate the reasons why, despite the measures taken by the State, the favorable for foreign pupils legislation, the projects undertaken, dozens of seminars, teachers' further education etc. the venture often fails.

This third publication that touches the problems that thwart the multicultural attempt, reveals objective difficulties not only from the perspective of the researcher but also the teacher, as, so far, the element of empathy has touched everyone but him/her and who has been attacked and characterized as ineffective every time something goes wrong. This publication concerns the difficulties that derive from the cultural gap which, despite teacher's efforts, remains unbridgeable. Our personal experience coincides with the confessions that follow.

\section{Findings}

The findings are highly revealing and, in some cases, prophetic of today's situation. Nevertheless, some researchers were then silenced or censored by senior scholars. The latter either adapt the findings of studies on the basis of their political beliefs or isolate researchers with different views due to security reasons so as to fit in with existing international data, overlooking the coming changes and distorting the new reality. After all, Greece plays the role of a bridge between East and West and is one of the first countries affected by such movements.

This new reality is unbearable for the school head, who is expected to keep balance among the school staff, the local society and the newcomers, (in case of conflicts arisen inside school), between national interest and the new globalized reality that threatens nation-states, between western culture and customs coming from non-western countries.

Unfortunately, whenever the state fails to lift the burden of foreign presence, it displaces it to school, giving little guidance to the school staff. However, when guidance proves to be fruitless, the state talks about ineffective leaders and teachers. The same counts for senior academics, who talk about inadequate teachers lacking sufficient education and qualifications (Tzifopoulos, M., 2018) to ensure financial sponsorship in order to implement teacher training programs. All the above are theoretical, as they do not provide any material but only give guidance as long as funding is available. The latter will be discussed in detail in a forthcoming article.

In the new data on the issue, teacher's and school head's opinion is never taken into consideration. The public school looks like a "caldron", where all types of students - students with behavioral disorders or learning disabilities, autistic pupils, foreigners, heterodox pupils, Roma students, etc- are thrown.

The cases examined here are those of Roma students, Muslims, Albanians, ex-Soviet citizens and children of mixed marriages. In the latter, association with Greek pupils and adoption of Greek culture depends on their own cultural background, because North Europeans usually 
have a sense of superiority over Greeks, as a school director confirms:

[...]I got a British student who doesn't want to speak Greek. Of course, in his case this happens for another reason. He does not want to speak Greek for reasons of superiority. (...) The English boy does not want to speak, because he considers himself superior to us. He understands them (the teachers) but doesn't want to talk. (Int. 46)

In cases like this, it is out of the question to expect the development of communicative competencies, as it is suggested by academics (Nussbaum, 1997). In most cases, this negation happens under the instructions of an adult.

That doesn't happen with the Northern European alone. After the fall of communism in the neighboring Albania, thousands of Albanians migrated into Greece. A School Coordinator, who supervises schools of a quite extended area, is quite frustrated seeing his efforts going down the drain:

\section{How do foreign parents deal with the difficulties of their children's education?}

Regarding this case, I can't generalize. There are people who do what they can to help their child learn Greek and help as much as they can, but there are others who give you the impression that they do not want to. When, for example, you tell them, "Let your child stay in full-time school, since no one is at home to help it," and you inform them that the child will do homework with the teacher, etc., he/she will have a greater chance of interacting with other kids, talking... the parent says "No, I don't want to." I do not know how someone could interpret it, unless the parent does not want to get too involved with Greek culture. (int. 10)

However, the subject 32 (headmaster at a school where almost all students are Muslims) does not seem to agree with this view. On the contrary, she considers that those who run schools with Albanian students are in a more advantageous position than herself. Moreover, there is another issue that troubles the following school directors/sses:

[...] Some parent told me: "We (Albanians) say: "If you do not punish a child when they do something wrong, they will not learn what is right". This has to do with the culture of the origin country. We have left behind such attitudes many years ago. I've seen this several times. Let's face it: When has the issue of domestic violence been raised? [...] (Int. 11)

My most negative experience was when I saw a $5^{\text {th }}$ grade student coming one day to school in shabby shoes and some marks on his body, which, as he claimed, were done when he fell on the stove. I wasn't convinced it was really so. I tried to be very discreet because the issue was sensitive but I formed the opinion that the child had a negative family experience a few hours before coming to school. It was a very unpleasant experience for me [...].

Did you bring an action to investigate whether there were issues of domestic violence?

Yes, I tried very discreetly, because I did not want to add an extra problem to the child, 
but I could not find anything to start procedures. (...) I was left guessing ... like the rest of the teachers ... of course. (Int. 25)

In the early 1990s, the Soviet Union collapsed and many Greeks repatriated. Along with them, many others, pretending to be Soviets of Greek origin migrated to Greece without documents. So, the same and worse situation is described in schools with students from the former Soviet republics:

What I clearly remember and left me dumbfounded were the fights taking place in Z... where I was serving as a teacher back in the 90's, when the so-called Russian-Pontiacs arrived ... the barbarity shown by children when they quarreled. The unjustified violence, so to speak. They didn't punch one another once and they stopped. In a bloodthirsty way, let's say. That made - I still remember - a terrible impression on me.

\section{Were they really Russian-Pontiacs?}

They didn't know Greek. They were called Russians. (Int. 22)

Next case examined here is the one of children of Roma origin. Throughout centuries, Roma people have worked as peddlers, land workers in the fields of Greek feudal lords, metalworkers constructing or repairing agricultural tools or instrument players who cultivated folk music (Deligiannis, 2013:40). Since 1960, the Roma choose permanent installation, though not always, something that prevents them from regular school attendance. In 1970's, during the period of dictatorship, the Roma were officially given the right to obtain Greek citizenship (Deligiannis, 2013: 62, Parthenis, Fragoulis, 2016:42-3). Prior reports by ECRI (2000, 2004, 2009) accused Greece for not taking enough initiatives in the field of Roma children's education. The truth is that only $10 \%$ of school-age Roma children attended school regularly (2011 census data). Ever since though, the situation was reversed. The State has taken serious measures for their education, aiming at the group's social integration. However, even nowadays, high drop-out rates and irregular school attendance can be noticed.

Do you believe that the current legal framework facilitates the education (turnout, attendance) of "different" children and their school success?

To a superlative degree, I think. They are already enrolled without the necessary supporting documents in the school unit. And that I think is... it keeps the doors open in a school that offers education to any citizen who lives in this society, in this country. (Int. 16)

Apart from the absence of the necessary documents, a Roma pupil is allowed to attend school without having been vaccinated for contagious diseases (like Greek students have), while, at the same time, they are provided with free meals from Niarchos Foundation and benefits from the State, as a directress confirms:

\section{Do you think that children's culture prevents them from attending...?}

Definitely. Definitely. Definitely. There is no necessary interest from the family, from home. Their education is not a motivation. The motivation may be to get rid of their 
children during those hours. The children could come to school as long as they have some benefits... that also works as an incentive. For example, food is an incentive to send their children. The benefits they once received is an incentive for their children to attend classes at school. (Int. 32)

Despite the measures taken and teachers' fight to give the best to these children, the attempt fails due to a variety of reasons:

I think that there is encouragement to child's progress in the culture of foreigners. On the contrary, family can sometimes be a hindrance for Roma pupils. Roma parents believe that the role of the school is not important. One minor incident happens and children stop attending [...]. (Int. 40)

\section{Has there ever been a flag-bearer issue in your school?}

No, because these students (Roma Muslims) are not like other foreigners who study regularly and monitor their progress. They are not so interested. (Int.32)

I can say, since school is not one of their priorities, they remind me of my past. To give an example: when my father went to school, he found a friend and said: "Let's go chasing birds." They hung the bag on a tree and went hunting. Of course, this is not the case today but, due to the families'financial conditions, school is not their top priority and they are right. Their motto is: "Even if I send my child to school, he/she will become a land worker, either having finished the elementary school or not." We're trying to make them understand that, even if they are land workers, school will surely be a "window» for a better life.

Does this denial have anything to do with the culture, the cultural background of these children?

Hmm! I wouldn't say that. I don't think there is a race, a tribe, call it as you want, that does not want to be educated, etc. I think from my experience - because I have spent so many years with these people - I think it has more to do with time waste: a child attending elementary school, then going to high school, and this takes 12 years. This means that, instead of receiving from their children, the family should provide for them. Other groups invest upon their children's education hoping of future achievements due to education. Bearing in mind that the child will later pick up iron, become a land worker etc, Roma parents find it a waste of time and money for their children to attend school." (Int.50)

Prompted by the phrase underlined above, it is necessary to clarify the reasons that make these children abstain from education. One more reason for that is because they are exploited by the own parents, as a School Coordinator confesses:

There was a time when I was participating in an awareness program financed by the EU. The purpose of the program was to find information about Roma students who left school and ended up in streets, keep records of them, the reasons why they are beggars etc. To my great surprise, I realized that it was the children's parents that didn't send them to 
school but forced them to work, in order to earn a considerable amount of money. Every such family has 4-5 children. So, imagine how much their father was earning every day without working. [...] (Int. 19)

The latter example is an "open secret" and it is not an isolated incident but, on the contrary, it happens all over the country. When these children decide to attend school systematically, the problems caused make directors/sses skeptic and uncomfortable:

Once I had a 14 year old Roma student in N.... One day, I found out with terror that, during the breaks, he played street dice with younger children. He even used Pokemon lids for this purpose and, in this way, he used to steal other students' cheese pies. The result was that the rest of the students stayed hungry every day. His view was that the big fish eats the little one. (Int. 49)

If so far the reader considers all of the above to be a common situation, (s)he would rather read the following passages from a recent interview in the field of "Leadership and Gender" and which describe a chaotic situation. The head teacher serves in a school unit where students are exclusively of Roma origin, who live in a deprived area in the Region of Eastern Macedonia and Thrace. Issues such as teachers' expectations, transmission of knowledge are simply out of context. In this particular area, the lifestyle of the locals becomes a nightmare for the manager and the teachers:

Your role entails a burden of responsibility. Are there times when you feel that it is too big or that it causes you so much stress that you can even have it physicalized?

I feel that this school, due to its particular conditions, has a lot of responsibility. In no other school has the burden been so unbearable. I felt it so many times because I lacked partners... (partners, hmm, support staff I'd rather say to make it clearer) and that made the load even heavier to me. That is to say, the local staff, $D . .$. , the auxiliary staff, did not really help and I had to keep my mind on school during holidays, because they (the locals) were stealing, they were ... and that was unbearable. On the other hand, while I was working with colleagues who knew the job, and the cooperation was great, it did not bother me.

Are you accountable for theft at school?

Yes, all year long.

\section{And what did they usually steal?}

They usually broke in and... they stole all the air-conditioners, because there were a lot of prefabricated classrooms at the backyard... actually all of them are prefabricated... 20 prefabricated classrooms equipped with air-conditioners... they started by stealing the air-conditioners... they broke in and used the room as a ... love nest, they caused damages (desks, chairs), lots of dirt... uh... once, some cables started getting fire... the fire brigade came... generally, you are constantly stand by. [...](Int.57)

When we asked the directress whether this entire situation causes her stress and whether this 
stress caused somatic symptoms, she explains:

Physically... I don't know... this thing caused a phobia to me. That is to say, the phone rang (I do not know whether this is physical) and when I saw the caller ID (the name of the school caretaker), I screamed "Mother Virgin!" I was terrified, that is... I was astonished, my heart was beating loud "What happened again?" that much... but now we've changed... (changed, hmm! Thank Lord, he moved to Germany for work!), we found a very good janitor who was not local and I calmed down (hilarious laughs). It sounds very stupid but indeed. (Int.57)

In such school units, the pursuit of students' academic progress is like building castles in Spain:

[...] Basically the responsibility is to prevent students from getting harmed, because they do not follow rules... Are you recording all that? Ha! Ha! Okay. I don't mind [...] They are very naughty. Have you noticed? There are railings not only all around the yard but also outside the window of every classroom and, during the break, 7 teachers supervise them, so that they won't bunk off! Their mind is constantly focused on how to bunk off! Ha! Ha! They perch on the railings all the time... inside the classroom and during lesson time, they constantly attempt to "escape" through the windows! The teacher locks the classroom, as soon as he comes in and when he comes out, he locks again. For their safety basically. Many times you can see them on the basketball net! Well, now with regard to the roof, it's something very common to me and I forget to mention it. They 're climbing the roof all the time! Do they find it entertaining? I do not know. Needless to mention what happens during our absence in the evenings. Aaaaaall the neighborhood is inside the schoolyard and on the roof!!! It's their favorite game... When I first came to see where the school was, I saw them hanging on the cables and moving on and I said, "Oh, Virgin Mary!"

\section{What cables? PPC?}

Such cables. Yes. Basically we have this. And what I say to my colleagues and I wish every day: "May we leave from here safe and sound. Learning multiplication table, as well as subtraction and addition is a secondary goal. My wish is to come and leave safe and sound. [...] (Int.57)

After all these stories, I seized the opportunity to ask this directress, if this minority group distrust her because she is a woman (according to them, women are considered to be inferior to men) and, therefore, they adopt disrespectful behaviors. She recalled a painful experience she had with a pupil's father, explaining:

I don't know whether he did this because I'm a woman or he would have done the same to a man, because local society is weird: we have some people here who just came out of prison, we have a lot of drug addicted parents - many of them coming in so aggressively and we have to face them. So I don't know if it's due to their race or their temperament. They might also do that to a man. (Int.57) 
In the lines above, the directress has made a very important point: many of these groups have a culture of drug use that is passed down from one generation to another. So, dealing with them becomes more and more difficult. In the following lines, the directress exposes a few more difficulties she encounters, some having to do with bureaucracy, as Roma people are constantly moving:

Every day we are basically occupied with procedural questions that concern the students like: from early in the morning we come here searching for solutions for their transportation, those who have recently arrived and they do not know which class they should attend because they were absent for a long time. Additionally, those who have been to Germany and did not get any documents but need papers, send their children first and then parents follow. We also have to do with parents who demand from us to provide them with certificate of attendance, while their children do not attend school (because they want to get benefits) and then, the neighbors protest: "Why did you give him the paper? Give it to me too, since his child was not coming as much as mine" We face such situations, yes ... then ... what else? Furthermore, we have the suppliers, who bring food to the kids at school - so they get breakfast daily from a program..." (Int. 57)

So far, we have exposed many different aspects concerning Roma education from many different colleagues. All the latter have underlined the high degree of teachers' professionalism, the extra time devoted to support pupils' learning and their participation in programs coordinated either by Universities or by School Coordinators. However, as it is understood, despite the State's concession and incentives, students are either absent from school or they go without changing all these bad habits that are counterproductive to learning, although according to a director:

[...] Gypsies and Muslims are not the same. They don't care so much about knowledge. If anyone knows how to read medication instructions, they see him as God. (Int.29)

Similarly another director claims:

[...] Here is an example: some applications for acceptance and participation in the soup kitchen program had to be signed. They couldn't even read them. They all came out of my door and waited to explain it to them, to write it for them, to complete the application the consent form. It definitely has a heavier burden. (Int. 50)

Of course, many principals find a challenge behind all that, show empathy towards foreign students, as they themselves were immigrant children and argue that a strong school with a strong culture can handle all the difficulties that come from such a blend. We need stricter legislation and police intervention, when the situation is out of control to face this aspect of juvenile offending as well as parents' disobedience to State's legislation concerning children's education.

The last category of pupils we examine in this article is the group of Muslim students. As suggested before, some directors/sses underlined the students' negation to incorporate and interact with Greek Orthodox students: 
Do you mean those of Albanian origin as well? 'Cause there is difference. Those of Albanian origin do wanna be incorporated, do wanna integrate into Greek society. The Muslims don't! They hold some of their own clear stereotypes and have their limits. They refuse cultural homogenization. Their religion inherently inhibits them. It keeps them away. It does not allow them to socialize. (Int. 32)

Again, racial habits return:

[...] What may be embarrassing is their bad language, because - it is not their own feature- they hear what their parents say, (the latter are usually more foul-mouthed), and do not think it is bad to reproduce what their parents say. [...] Perhaps our own Greek-Orthodox children might say the same words but they know when the time is proper. (Int. 50)

\section{Is there violence in the family environment of these children? Is there violence in their culture?}

It's in their culture. For this particular group there in A... there is violence in their culture. For example, if a child disobeys the rules of the family, it will be completely shaved! They leave him totally bald! This is violence. This incident happened at school.

\section{To stigmatize the child?}

Yes, yes, as a method of punishment. (Int. 32)

In a previous article (Matziouri, Tsioumis, \& Kyridis, 2014:7), we emphasized the serious dangers pupils of few schools faced due to the presence of a peculiar group of German pupils with serious mental and psychic disorders. The director's despair was summed up in the phrase: "[...] we all pray nothing to go wrong." This issue has been raised again on the occasion of Muslim students.

The narrative that follows concerns a tremendous experience that a teacher who worked in intercultural school faced 10 years before our research (year 2003):

Can you recall some incident that has been engraved in your memory and caused you positive or negative representations for the foreigners?

I am very receptive by nature and I love to offer my services to society - that's why I have chosen to become an educator. What I will never really forget was when I had a fifth class, at the 16th intercultural school, in the prefecture of Ch... I had 29 pupils only 6 of whom were Greeks. I had pupils from Kenya, Bulgaria, Ukraine, Syria, Palestine, many Albanians... Those from the Gaza Strip - from Palestine - were members of the parish of St. N..., lodged in the orphanage of the region and attended the intercultural school. So what I'll never forget is an incident between a student from Bulgaria and a student from Syria, whose brother at that time - according to what Mohammed, my student told me was in Jihad (armed struggle against unbelievers) in Palestine. It was the 2nd or 3rd Intifada, I don't remember what was happening then. So, he was very tensed and nervous concerning the issue of religion. Suddenly, he began to show negative behavior towards 
Christians and hostility to a classmate. So, one night he took his pencil and scraped it -I don't know exactly what he did but he made it look like a lance. So, suddenly, during our Geography class, I hear a loud "Jihaaaad" in the classroom and I see Mohammed jumping over the desks and nailing the pencil - which he had sharpened like a lance - to the neck of the Bulgarian boy. This will be an unforgettable experience and, ever since, I took a vow that this would never happen again not only in my own class but in all Greek schools. That is exactly what I was telling you before: theory is one thing, practice is another. I regret being unable to detect some aspects of his culture - what can I say? - a penny of his thoughts... I think if I had been better trained, I would have figured it out. (...)

\section{How did you handle this afterwards? What did you do?}

Apart from taking the student to the headmaster, tell me, what else could I have done? Lose my temper? Start yelling? I took the second pupil (the "victim") to the P.E. teacher and called for an ambulance to get him. Meanwhile, the headmaster took the responsibility to talk to Mohammed and after contacting the orphanage... well, I don't know the decision made, but there was surely a moving to a new school. Who won and what did he win??? It was an intercultural school and, as you understand, this kid would eventually end up in the Gaza Strip fighting in a war, just? Unjust? I can't judge it. What did we do to anticipate this? It is the Ministry's obligation, as long as we live in a globalized environment, to prepare us for such a thing. How? I am not sure.

\section{When you called the injured child's parents, do you remember how they reacted? Did you have problems with his parents?}

The parents of the child from Bulgaria... hm... you know... "The f...e Muslim, the god damned ...". Thank God they did not file a lawsuit. "What do you expect from a Muslim? From a filthy $s$... of a b...? "I 'm still wondering: what if this had not been done by a Muslim but by George, a Christian, a Catholic, what would these people say? I think this is the point where the Ministry's management and virtuosity lies: to organize education programs for parents, to be engaged in a process of organizing it to such an extent that we shall not be the only ones being trained. Society should get involved in a process of self-education. How am I supposed to say it; [...] (Int. 49)

The prementioned is now verified by the current situation in various settlements - and not only - where illegal immigrants live (the number of actual refugees is negligible, they don't come from war zones, they don't possess any documents and they are registered with 3-4 different names, 3-4 different countries of origin, according to police reports(note 1)) with incidents of extreme violence and many child rapes happening on a daily base among (non) adults of the same religion but of different nationality, pillaging, desecration of Christian churches (Patrick Wintour(note 2), The Guardian, $2^{\text {nd }}$ of May 2019). All the above verify that, contrary to what some researchers (Damanakis, 2002) suggested (as culture is a subcategory of civilization and civilization is anything that is compatible with human nature and human soul), there is a myth behind the so-called "equality" of cultures. The situation is totally out of control and dangerous for a teacher who would like to offer his service for immigrant 
children. The most alarming is that, according to the Greek legislation, a foreign pupil is allowed to study in primary education until the age of 15 . How will the Greek teacher correspond and guarantee the safety of pupils, when thousands of foreign students join the Greek public school in the name of so-called "integration"?

\section{Conclusions}

We analytically revealed, through many subjects' narrations, the present situation and how they experience it. In contrast to other researches (Lareau, 2003), our research has proven the high degree of school staff's willingness to assume responsibility for the education of all children, taking into account their socio-cultural characteristics. Furthermore, we saw teachers and school heads being accountable to high-rank leadership and afraid to lose their job. In these terms, it is out of question to talk about self-fulfilling prophesies (Cummins 2001) or ignorance of social structures, reproduction of inequality (Ross \& Smith, 1992; Gay, 2002; Schoorman, 2002), symbolic violence and "habitus" (Bourdieu, 1990). Additionally, it seems like a pipe dream in cases like these to talk about deciphering codes (Skrefsrud, 2018) or fostering cohesion and unity (Osler, 2005: 3), promotion of an overarching set of shared values, ideals and goals to which all can adhere (Banks, 1997).

Somebody might claim that people who have grown in violence reproduce such behaviours, but extreme violence and autarchy have always been prevalent in specific regions of the globe throughout millennia. And let's face it: all those arriving in an advanced country do not have the profile of a refugee or immigrant, quite often they have migrated with questionable intentions towards the western culture and they are supported by agents that undermine national territories in many different ways. Having that knowledge and not intending to be burdened in any way, the European Union has made a lot of declarations for the refugees' rights of but sealed its borders (we will refer to this parameter more analytically in another article).

A reasonable person may wonder: In this new reality are we, in the western world, willing to change morals and customs or are we going to keep on letting sleeping dogs lie??? Are we going to modify our legislation and adapt it to the customs of East or Africa, permitting extreme forms of violence for reasons of honour or religion in our own country? Are we broadening our horizons through multicultural education or are we letting the Trojan horse in???

Multicultural education is supposed to cultivate an open dialogue between cultures. That presupposes open-mindness and good will on both sides. It also needs idealists and respect from both sides. For this reason, we choose to close this article with a poem by the Persian poet Jalal al- Din Rumi (1207-1273), which is an invitation for people to overcome divisions and differences:

Come, come, come again

Come no matter if you are an unbeliever, a pagan

Or a fire-worshiper 
In the corner of my house there is no threshold of despair

And if you've broken your vows a hundred times

Come again.

\section{References}

Blount, J. M. (2006). Comparative historical analysis as a way of understanding social justice work in education. Paper presented at the Annual Meeting of the American Educational Research Association, San Francisco, CA.

Bourdieu, P. (2000). Pascalian meditations. Palo Alto, CA: Stanford University Press.

Cummins, J. (2005). Negotiating Identities: Education for Empowerment in a Diverse Society. Translation: Argyri S. Athens, Gutenberg, p.170.

Damanakis, M. (2002). Intercultural Pedagogy in Greece. Practical Issues and Theoretical Questions. Sciences of Education- thematic volume "Intercultural Education in Greece", Athens: Atrapos.

Dantley, M. E., \& Tillman, L. C. (2006). Social justice and moral transformative leadership. In Marshall, C. and Oliva, M. (Eds), Leadership for Social Justice: Making Revolutions in Education. Pearson/Allyn and Bacon, Boston, MA, pp. 16-30.

Darling-Hammond, L., \& Lieberman, A. (2012). Teacher Education around the World: Changing Policies and Practices. New York: Routledge. https://doi.org/10.4324/9780203817551

Deligiannis, S. (2013). Roma Communities in Greece, Discriminations \& Stereotypes. The case of Sophathes in Karditsa, University of Patra, Faculty of Social Studies, Department of Social and Educational Policy, Program of Postgraduate Studies "Social Discriminations, Immigration and Citizenship".

ECRI. (2000). Second report on Greece. Strasbourg, FR: Council of Europe.

ECRI. (2004). Third report on Greece. Strasbourg, FR: Council of Europe.

ECRI. (2009). Fourth report on Greece. Strasbourg, FR: Council of Europe.

English, F. W. (2006). Towards a theory of social justice/injustice: learning to lead in the social cage. Paper presented at the Annual Meeting of the American Educational Research Association, San Francisco, CA. p. 2.

Evans, S. D., \& Vergnaud, S. (1998). Pedagogical engineering in intercultural teams: critical success factors. International Journal of Educational Management, 12(4), 149-153. http://dx.doi.org/10.1108/09513549810220605

Furman, G. C., \& Shields, C. M. (2004). How can educational leaders promote and support social justice and democratic community in schools? Paper presented at the Annual Meeting of the American Educational Research Association, Chicago, IL. 
Furman, G. C., \& Starratt, R. J. (2002). Leadership for democratic community in schools. In Murphy, J. (Ed.), the Educational Leadership Challenge: Redefining Leadership for the 21st Century, National Society for the Study of Education, Chicago, IL, 105-133. https://doi.org/10.1111/j.1744-7984.2002.tb00006.x

Gay, G. (2002). Preparing for culturally responsive teaching. Journal of Teacher Education, 53(2), 106-16. https://doi.org/10.1177/0022487102053002003

Gillborn, D. (1995). Racism and antiracism in real schools. Philadelphia, PA: Open University Press.

Grant, C. (1990). Desegregation, racial attitudes, and inter-group contact: a discussion of change. Phi Delta Kappan, 70, 25-32.

Grogan, M., \& Andrews, R. (2002). Defining preparation and professional development for the future. Educational Administration Quarterly, 38, 250. https://doi.org/10.1177/0013161X02382007

Gropas, R., \& Triandafyllidou, A. (2011). Greek education policy and the challenge of migration: an 'intercultural' view of assimilation, Race Ethnicity and Education, 14(3), 399-419. https://doi.org/10.1080/13613324.2010.543394

Hearnden, M., \& Sundaram, V. (2011). Education for a Diverse Society: The Multicultural Classroom in the UK. In: Spinthourakis J., Lalor J., Berg W. (Eds.), Cultural Diversity in the Classroom. VS Verlag für Sozialwissenschaften, 187-197. https://doi.org/10.1007/978-3-531-93494-5_12

Kontogiannopoulou-Polydorides, G., \& Fragoulis, G. (2009). Teachers' perceptions and practices regarding reading literacy of diverse student population in primary school. In E. Tafa \& G. Manolitsis (Eds.), Emerging literacy. Research and applications, 195-204. Athens, GR: Pedio.

Lareau, A. (2003). Unequal childhoods. Los Angeles, CA: University of California Press.

Luciak, M. (2006). Minority schooling and intercultural education: A comparison of recent developments in the old and new EU member states. Intercultural Education, 17(1), 73-80. https://doi.org/10.1080/14675980500502370

March, J. G., \& Simon, H. A. (1958). Organisations. ISBN 9780631186311 (1993).

Matziouri, A., Tsioumis, T., \& Kyridis, K. (2014). The Views of School Administrators and Educational Authorities Concerning the Management of Multiculturalism in a Regional Unity of Northern Greece. Journal of International Education and Leadership, 4(1), 7.

May, S. (ed.) (1999). Critical multiculturalism: Rethinking multicultural and antiracist education, London: Falmer.

Nussbaum, M. C. (1997). Cultivating Humanity. A Classical Defence of Reform in Liberal Education. Cambridge, Massachusetts, Harvand University Press. https://doi.org/10.2307/j.ctvjghth8 
OECD. (2014). Education at a glance. Paris, OECD.

Ogrodzka- Mazur, E. (2018). Intercultural Education in Poland: Experiences, Problems and Prospects. In O.B. Cavero \& N. Llevot (Eds.), New Pedagogical Challenges in The $21^{s t}$ Century. London, IntechOpen. https://doi.org/10.5772/intechopen.71010

Osler, A. (2005). Looking to the future: Democracy, diversity and citizenship education'. In A. Osler (Ed.), teachers human rights and diversity, Stoke on Trent: Trentham Books, pp. $3-22$.

Parthenis, C. (2014). Education of Roma children: Developing intercultural understanding and training skills for teachers through distance learning and a constructivist teaching model. Text under publication for the Proceedings of the " 1 st International Conference on New Developments in Science and Technology Education".

Parthenis, C., \& Fragoulis, G. (2016). "Otherness" as Threat: Social and Educational Exclusion of Roma People in Greece. International Journal of Multicultural Education, 18(2), 39-57. https://doi.org/10.18251/ijme.v18i2.1132

Place, A. W., Ballenger, J., Wasonga, A. T., Piveral, J., \& Edmonds, C. (2010). Principals' perspectives of social justice in public schools. International Journal of Educational Management, 24(6), 531-543. https://doi.org/10.1108/09513541011067692

Police-Voice news. (2 June, 2020). Quiz: One immigrant- 3 names, 3 surnames, 3 countries of origin- How many benefits does he receive? Retrieved from https://www.police-voice.com/2020/02/3-3-3.html

Polycarpou, D., \& Athanasoula-Reppa, A. (2018). Strategies of handling collisions in primary schools, $25^{\text {th }}$ International Conference. Intercultural Education, Greek as second or foreign language, Diversity, Refugee Structures, University of Patra, Convention and Cultural Center, $22^{\text {nd }}-23^{\text {rd }}$ of June 2018.

Rumi, J. D. (1997). The beloved, ed. Harmos. translation: Kadio Kolymva, Introduction, p. 22.

Ryan, J. (2003). Leading diverse schools. Dordrecht, NL: Kluwer. https://doi.org/10.1007/0-306-48084-0

Schoorman, D. (2002). Increasing critical multicultural understanding via technology: "teachable moment" in a university-school partnership project. Journal of Teacher Education, 53(4), 356-369. https://doi.org/10.1177/0022487102053004007

Skrefsrud, T.-A. (2018). Intercultural learning in diverse schools: obstacles, opportunities and outlooks. Issues in early education, 3(42). https://doi.org/10.26881/pwe.2018.42.08

Skrefsrud, T.-A. (2018). Barriers to Intercultural dialogue, Studies in Interreligious Dialogue, 28(1), 43-57. https://doi.org/10.2143/SID.28.1.3285343

Sleeter, C. (2013). Teaching for Social Justice in Multicultural Classrooms. Multicultural Education Review, 5(2), 1-18. https://doi.org/10.1080/2005615X.2013.11102900 
Spinthourakis, J. A. (2006). Developing multicultural competence through intercultural sensitivity. International journal of migration studies. Migration Studies, XLIII(163), 641-656.

Taguma, M., Shewbridge, M., Huttova, J., \& Hoffman, N. (2009). OECD Reviews of Migrant Education. Paris, OECD, 8. https://doi.org/10.1787/9789264086210-en

Tzifopoulos, M. (2018). Preparing the "majority" for the education of the "minority": experiences and speculations, conference proceedings of $25^{\text {th }}$ International Conference. Intercultural Education, Diversity, Refugee Structures, Greek as second or foreign language, Patra, 22 ${ }^{\text {nd }}-23^{\text {rd }}$ June 2018, 185-201.

Wintour, P. (2019). "Persecution of Christians 'coming close to genocide' in Middle East" in the Guardian. $\quad$ Retrieved 2 May, 2019 from https://www.theguardian.com/world/2019/may/02/persecution-driving-christians-out-ofmiddle-east-report

Yeo, F. (1997). Teacher preparation and inner-city schools: sustaining educational failure. Urban Review, 29(2), 127-143. https://doi.org/10.1023/A:1024686607759

\section{Notes}

Note 1. https://www.police-voice.com/2020/02/3-3-3.html

Note

https:/www.theguardian.com/world/2019/may/02/persecution-driving-christians-out-of-midd le-east-report

\section{Copyright Disclaimer}

Copyright for this article is retained by the author(s), with first publication rights granted to the journal.

This is an open-access article distributed under the terms and conditions of the Creative Commons Attribution license (http://creativecommons.org/licenses/by/3.0/). 